\title{
WHY HAS THE CENTRAL BANK OF EGYPT BEEN UNABLE TO ACHIEVE THE GOAL OF PRICE STABILITY UNDER THE ECONOMIC REFORM PROGRAM?
}

Ibrahim L. Awad*

\section{Introduction}

The most radical changes in macroeconomic policy in Egypt since the 1950s occurred in the early 1990s when the Egyptian government endorsed an agreement with the IMF and the WB, known as the economic reform and structural adjustment program (ERSAP). ${ }^{1}$ This agreement came into being in the aftermath of a critical economic performance of the Egyptian economy in the late 1980s, where the ratio of external debt (\% of nominal GDP) reached $131.7 \%$ and $115.23 \%$ in the years 1988 and 1989 respectively. ${ }^{2}$ The ERSAP incorporated two broad objectives, namely (i) switching the economy to a market-based economy via price liberalization, FX rate, interest rate and trade; and (ii) stabilizing the economy and rectifying macroeconomic policies.

Because the ERSAP represents a watershed between two identifiable phases of macroeconomic policy in Egypt, this paper assesses the performance of the monetary policy during the periods following the introduction of the ERSAP. It sets out to answer the question why the central bank of Egypt (CBE) has not been able to achieve the goal of price stability under the ERSAP. ${ }^{3}$ I organized this paper as follows: Section 2 highlights the monetary policy objectives and tools under the ERSAP. Section 3 assesses the performance of the monetary policy under the ERSAP. Section 4 concludes.

* Zagazig University, Faculty of Commerce, Egypt (ibrahimphd@yahoo.com).

1 Before the ERSAP, Egypt signed three stand-by agreements with the IMF, in 1976, 1978 and 1987. These agreements were very similar to the ERSAP. For social, political and economic reasons these agreements were discontinued. For more details about the ERSAP, see Awad (2002), Richards (2001), and Korayem (1997).

2 Calculated from WDI, CD-R 2008 where the total debt (USD billions) was 46.147 and 45.684 for the years 1988 and 1989 respectively, whereas the corresponding nominal GDP (USD billions) was 35.045 and 39.648 respectively.

3 An operational definition of price stability that is now broadly accepted among economists is the one presented by Alan Greenspan: price stability is obtained when economic agents no longer take account of the prospective change in the general price level in their economic decision-making (Batini et al., 2005, p. 161). 


\section{Monetary policy objectives and tools under the ERSAP}

Before the 1990s, the Egyptian economy was described as a centralized economy. Central planning and the public sector were dominating the whole economy; thus, economic policy was implemented by direct means, i.e., orders or instructions. As the government was controlling and managing the vast majority of prices, the function of prices as guidance for economic activities was disrupted in the whole economy. The private sector was not completely absent; however, its role was very limited (Awad, 2002).

Abu-Elayoun (2003) indicated that monetary authorities applied a monetary targeting regime during the periods before the ERSAP to achieve the goal of price stability but the association between the intermediate target, i.e. M2, and the ultimate goal of monetary policy, i.e. price stability, was not strong enough. Indeed, during these periods the CBE did not announce any targets for the monetary growth. In addition, the foreign exchange (FX) rate was pegged vis-à-vis the US dollar both during these periods and even after the introduction of the ERSAP until the start of 2003. Furthermore, the government was controlling an influential part of prices of goods and services in the economy and both fiscal dominance and financial repression were practised during all these periods.

\subsection{Monetary policy objectives under the ERSAP}

One of the most difficult challenges for a researcher is to determine exactly the objectives of the monetary policy that the CBE was actually intending to achieve, especially during the period following the introduction of the ERSAP in 1990, until the decision of floating the FX rate in January 2003. One reason for this is that the CBE adopted inconsistent objectives for its monetary policy during this period (Moursi, et al., 2007; Kamar and Bakardzhieva, 2003; and Panizza, 2001). ${ }^{4}$

After the introduction of the ERSAP, the ultimate objective of the monetary policy was determined to achieve both internal and external stability of the domestic currency in line with the national objectives of spurring economic growth and creating more job opportunities. During this period, the intermediate target of the monetary policy was determined to be the net of domestic credit and, later, the rate of growth in money supply (M2). The daily operational target of the monetary policy was determined to be banks' excess reserves (Abu-Elayoun, 2003). ${ }^{5}$

4 One example of such inconsistent objectives as Moursi, et al. (2007, p. 4) mentioned is that the CBE adopted conflicting objectives especially during the period 1992/1993-1996/1997. In 1992/1993, while the CBE aimed at controlling the monetary expansion, it also called for a reduction in the interest rate on the Egyptian pound to encourage investment and promote economic activity. During the period 1993/1994-1995/1996, monetary policy objectives were swaying between the two objectives of both economic growth and price stability. In 1996/1997, the CBE reverted to the objective of economic growth via monetary stabilization.

5 During the fiscal year 2002-2003, the monetary policy targeted the rate of growth of domestic liquidity at a rate of $10 \%$, irrespective of the changes in the exchange rate. The actual rate of liquidity growth reached 9.4\% (CBE, 2002-2003, p. 30). 
During the aforementioned period, from 1990 to the start of 2003, and for long periods the CBE was targeting the FX rate, as can be inferred from Figure $1 .{ }^{6}$

\section{Figure 1* \\ FX rate evolution (1960-2008)}

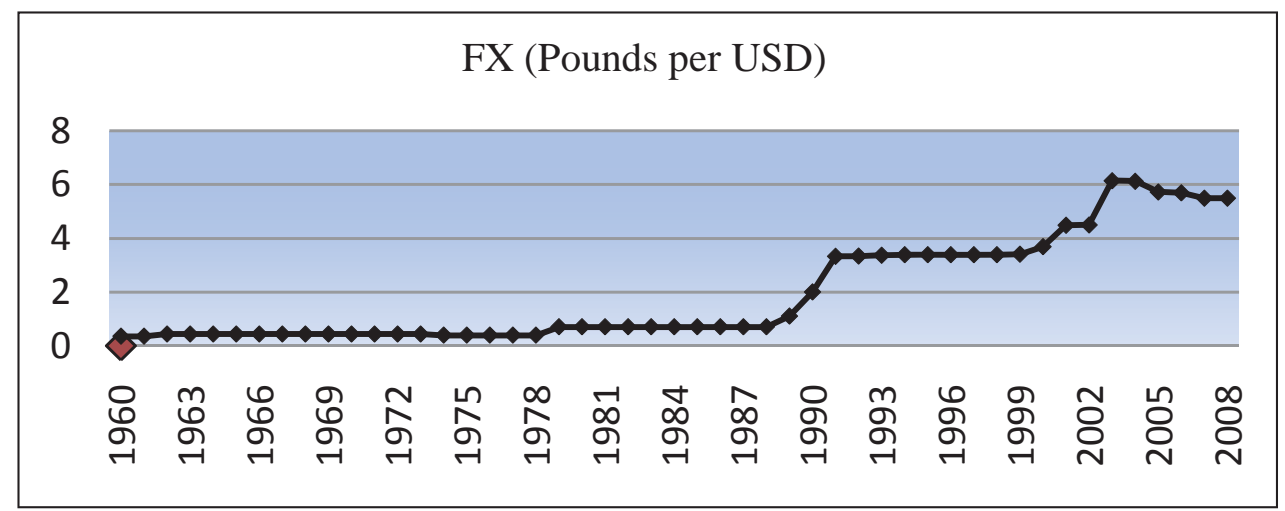

Source: Prepared using data from IFS, CD-R, 2010.

* Figures 1-10 designed by the author.

Taking into account that the CBE liberalized domestic interest rates on loans and deposits in 1991, ${ }^{7}$ one may ask how the CBE can maintain the FX rate target and, at the same time, achieve the goal of price stability through maintaining an implicit target for the money supply (M2). ${ }^{8}$ Because of this dilemma, the CBE was unable to efficiently use either a short-term nominal interest rate or banks' excess reserves to manage the monetary policy during this period, especially when the economy incurred external and domestic shocks in the latter half of the 1990s, as we will see later.

After liberalizing the FX rate and issuing new legislation in 2003, governing the $\mathrm{CBE}$, the banking sector and the money, the ultimate objective of the monetary policy has changed to focus primarily on the goal of price stability. Galal (2003) assesses the decision of floating the FX rate as an attempt to resolve policy inconsistency originating from the combination of FX rate rigidity, reluctance to use international

6 During the period 1960-2003, different varieties of exchange rate regimes had been experimented with in the Egyptian economy, i.e., conventional peg in the 1960s, crawling peg in the 70s and 80s, crawling bands in the 90s, and managed floating as of 2003. Beside the official price, the FX market witnessed multiple prices including prices of both a parallel market and a black market. In 2004, Egypt successfully unified its FX markets (Kamar and Bakardzhieva, 2003).

7 By January 1991, the CBE had liberalized interest rates on loans and deposits. Accordingly, banks were given the freedom to set their loan and deposit interest rates subject to the restriction that the 3-month interest rate on deposits should not fall below 12 percent per annum. This restriction was cancelled in 1993/1994 (Moursi, et al., 2007, pp. 6-7).

8 The sterilized intervention policy may give an answer to this question. Nevertheless, a sterilized intervention policy itself is fragile and can lead to dramatic consequences, as we will see in the next section. 
reserves to support the peg to the dollar, and the attempt to reduce the interest rate to activate the economy. ${ }^{9}$

As of June 5, 2005, the CBE developed a new framework for monetary policy implementation. This framework relies on the use of the overnight interest rate on the inter-bank transactions as an operational target for the monetary policy, instead of banks' excess reserves. The new framework represented the central bank's main policy instrument, providing the outer bounds of a corridor within which the ceiling is the overnight interest rate on lending from the $\mathrm{CBE}$, and the floor is the overnight deposit interest rate at the CBE (CBE, 2005-2006, p. 1).

\subsection{Monetary policy tools under the ERSAP}

Under the assumption that the influential part of inflation in the Egyptian economy refers to the demand side, the ERSAP was designed to fight the accelerating inflation which occurred in the late 1980s via controlling aggregate demand. That is why the CBE applied a contractionary monetary policy especially during the first stages of the ERSAP. By liberalizing the interest rate in 1991, the direct means to conduct monetary policy that were used in the previous periods (e.g., credit ceilings, interest rate ceilings, and discriminatory interest rates) were abolished. Since then, the CBE no longer determines the interest rate administratively but rather it affects market conditions using monetary policy tools to conduct nominal rates towards the desired path.

Liberalizing the interest rate coexisted with developing a new tool to finance budget deficit using real resources, especially in the first half of the 1990s. Treasury bills (TBs) were used intensively to play a central role and interest rates on TBs served as an indicator for the directions of both the short-term interest rate within the market and the discount rate determined by the CBE. By activating the TB mechanism, the nominal interest rate began to rise. As a result, the real interest rate registered positive values, especially when the rate of inflation began to recede during the first half of the 1990s.

Monetary policy tools used under the ERSAP are: (i) Open market operation (OMO); as the goal of price stability represents a cornerstone among the other objectives of the ERSAP, the CBE intended to restrict aggregate demand via absorbing excess liquidity in the economy. The preliminary step in this direction was the use of real resources to finance budget deficit rather than the monetary means that were used extensively before the ERSAP. The TB mechanism, as a new tool, was developed to

9 Despite formal liberalization of the FX rate in January 2003, the CBE continued to maintain exchange rate stability as one of its key objectives in the following years 2004 and 2005. That makes many commentators suspect that the CBE still has an implicit FX rate target and intervenes regularly to maintain it (Moursi, et al., 2007, p. 8). Al-Mashat and Billmeier (2007) examined the transmission mechanism in Egypt for the period from January 1996 to June 2005 using the VAR model. One result of this study is that the exchange rate channel is still playing a strong role in propagating monetary shocks to output and prices despite the CBE is, formally, no longer using the nominal exchange rate as a nominal anchor for its monetary policy. 
play that role. During the first half of the 1990s, the main focus was basically on the primary TB market. The role of CBE was just to organize the process of selling TBs to commercial banks and individuals on behalf of the government. ${ }^{10}$ During the latter half of the 1990s, the CBE aimed at maintaining price stability via stabilizing banks' reserves and hence stabilizing domestic credit and domestic liquidity. To achieve this objective, the CBE focused on the secondary TB market. Thus, repos and reverse repos were used extensively. In 2001, the CBE permitted repos for one night at the prevailing discount rate. In September 2002, the CBE shifted from accepting deposits in the local currency, in virtue of mutual agreements between the CBE and some other banks, to a new market-based system. According to the new system, the CBE specifies the quantity of deposits required to be deposited and the date and maturity of the transaction. On their part, banks are to submit their bids specifying the required quantity and interest rate (CBE, 2002-2003). ${ }^{11}$ As of August 2005, a new instrument dubbed "the central bank notes" was developed. These notes are issued with a maturity spanning up to two years and are used to absorb banks' excess liquidity, instead of the reverse repos of the TBs (CBE, 2005-2006, p. 6).

(ii) Reserve ratio: at the beginning of the economic reform, particularly in December 1990, the reserve ratio was cut from $25 \%$ to $15 \%$ and later to $14 \%$ of the total deposits. The method of calculating the reserve ratio was modified to include the average balances for a period of one week excluding official and end-of-week holidays with a time difference of two weeks between the numerator and denominator values. In March 2001, the CBE decided to exclude long-term deposits from the denominator of the reserve ratio (Abu-Elayoun, 2003). In the fiscal year 2002-2003, the CBE decided to modify the method of calculating the reserve ratio by extending the calculation period from one to two weeks, including official and end-of-week holidays. In addition, it was decided to exclude from the numerator of reserve ratio the balances of TBs whose remaining period of maturity does not exceed 15 days. The ratio is to remain in effect at its prevailing level of 14\% (CBE, 2002-2003).

(iii) Discount rate: during the first half of the 1990s, both the discount rates and the lending rates were associated with the directions of the short-term interest rate on 91-day TBs. Beginning in the latter half of the 1990s, this association was broken when the short-term interest rate on TBs declined and the discount rate was frozen by the CBE (Abu-Elayoun, 2003).

10 The inflation rate fell dramatically during this period (see Figure 6).

11 After the CPI-based inflation rate reached 12.4 percent annually in December 2006 compared to 7.2 percent in June 2006, the CBE continued its OMO to contain the inflationary pressures via absorbing excess liquidity in the banking system, resulting mainly from larger foreign currency inflows (CBE, 2006-2007). 


\section{Assessing the monetary policy performance under the ERSAP}

To gauge the performance of the monetary policy under the ERSAP, the study compares the economic performance during the period beginning in 1991 with both its counterpart in an advanced economy, e.g. Germany, during the same period, and with the economic performance of the Egyptian economy during the period before the introduction of the ERSAP, i.e., 1975-1990. Although inflation, unemployment, and real GDP growth are used to gauge the performance of the monetary policy, the behavior of the inflation rate is given priority as it represents the main objective of the monetary policy. To explain changes in these variables, particularly the change in the inflation rate, the study focuses on another group of variables related to fiscal policy, trade policy and monetary policy.

In what follows, the study sheds light on the economic performance of the Egyptian economy during the period 1975-1990, which represents a base period in our assessment of the performance of the monetary policy under the ERSAP.

\subsection{The economic performance during the period 1974-1990}

The period 1975-1990 can be divided into two sub-periods: the period 1974-1981, a consuming open-door policy period, and the period 1982-1990, a consuming open-door policy and the external debt crisis (Awad, 2002).

\subsubsection{The period 1974-1981}

Beginning in this period, the Egyptian government adopted an "export leading growth strategy". The government began to introduce more facilities to foreign and Arab investments by issuing Act no. 43/1974. The Egyptian economy became more oriented towards Western Europe and the USA compared with the previous periods. A large number of taxes that had been imposed on imports during the previous periods were cut. The role of the private sector in the economy began to revive once again. During this period, The Egyptian government applied an "open-door policy". One of the consequences of this policy is a deterioration in the trade balance because of the high scale of consuming imports (see Figure 3).

Although the government was controlling most prices, as in the previous periods, domestic prices surged during this period (see Figure 2). 


\section{Figure 2}

Inflation in the Egyptian economy (1975-1980)

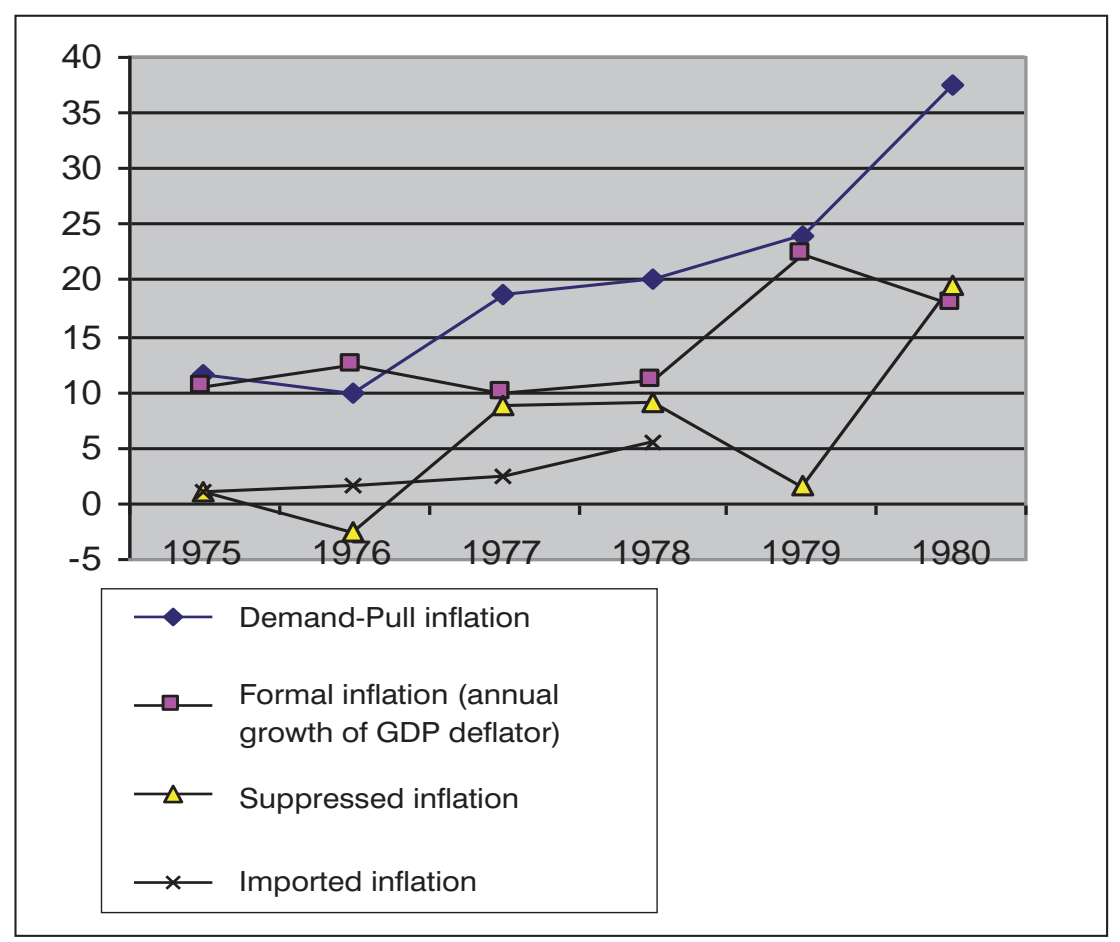

Source: Adapted from Awad (2002).

The rise in the price level was induced by both external and domestic factors. Because the FX rate was pegged to the US dollar and, at the same time, the inflation rates in the worldwide economy surged during this period, the domestic prices were affected negatively because of imported inflation. The prices of tradable and intermediate goods moved up as most of those imports were coming from Western Europe and USA, which witnessed the highest levels of inflation during this period. ${ }^{12}$

Domestic factors also played a central role in the domestic inflation. During this period, a notable improvement in the sources of foreign currencies occurred. Some of these sources refer to external factors, i.e., FDI, loans and grants, and others refer to internal factors, i.e., oil exports, tourism, the Suez Canal and remittances of Egyptian laborers abroad, especially in the Arabian oil countries. The improvement in foreign sources affected the aggregate demand and led to a demand-pull inflation. In addition, the structure of the aggregate demand might have changed because of a change in the consumers' preferences and the problems of urbanization.

12 During the period 1974-1978, the exchange rate was pegged and imported inflation was positive as reported by Awad (2002); thus, the domestic price level deteriorated during that time because of unfavorable shifts $n$ terms of trade. 
Another channel that may explain the high inflation rates during this period is the deficit in the general budget supported by bank financing. During this period, the government was still supporting food subsidies and controlling prices of basic goods. When the inflation rate increased on the world market, the government did not cut the food subsidies and continued controlling prices of public sector products, which were lower than market prices. Since most intermediate goods prices increased on the world market during this period, the public sector losses increased accordingly and hence budget deficit was exacerbated. The government was unwilling to impose additional burdens on people through higher taxes after the war of 1973. Thus, both external debt and bank financing of budget deficit rose dramatically during this period (see Figure 3).

\section{Figure 3}

Some indicators of economic performance (1975-1980)

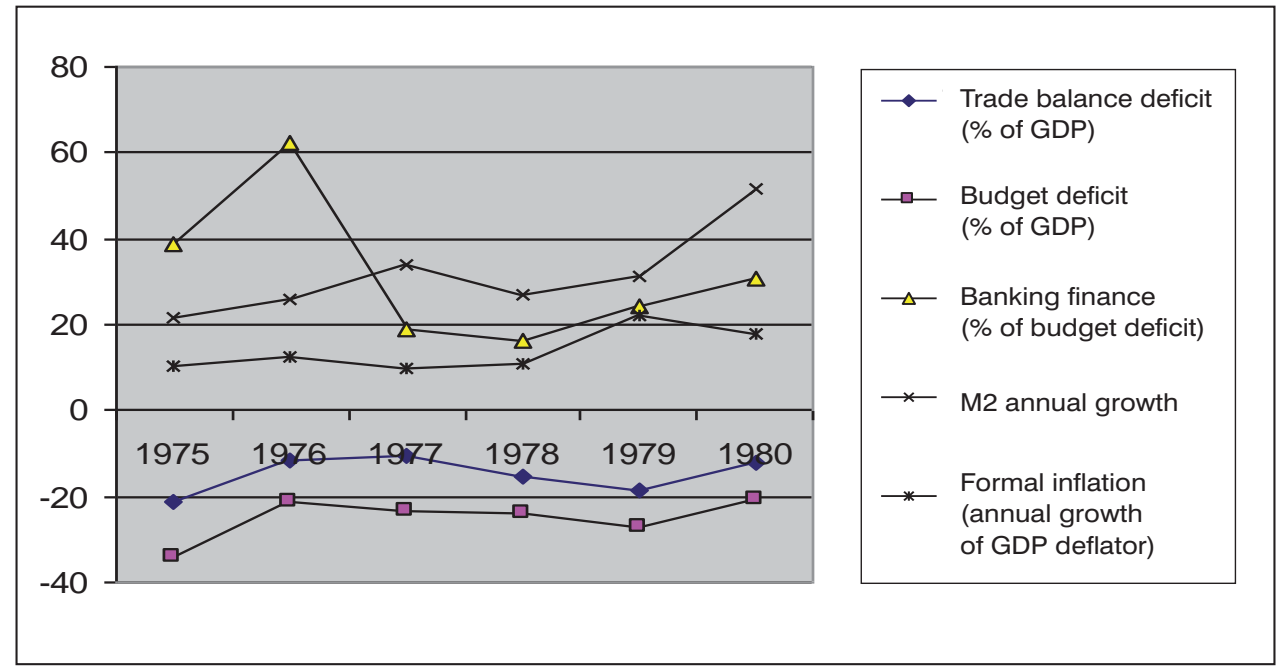

Source: Adapted from Awad (2002).

\subsubsection{The period 1982-1990}

During this period, the government stepped more towards encouraging the private sector. Act no. 43/1974 was superseded by Act no. 159/1981, which permitted foreigners a stake of $51 \%$ in business capital. The central planning, which had ended in the aftermath of the 1967 events, was resumed through articulating the second quinquennial plan over the period 1982-1986.

The most distinguishing features of the 1980s was the eruption of the unemployment problem. Nassar (1989) concluded that the investment policies during this period were anti-employment. Beginning in the latter half of the 1980s, 
the government moved gradually to relinquishing the adherence of appointing graduates because of successive public sector losses. During that time, the demand on Egyptian labor in the Gulf countries and Iraq was relaxed because of receding oil prices and higher competition from Asian and Indian laborers. As a result, the formal unemployment rate began to rise from $6.75 \%$ in 1986 to $9.6 \%$ in 1989 . The budget deficit (\% of GDP) registered the highest level during this period, e.g., 27\% in 1981 and 26\% in 1985. Banking finance represented the main tool to finance the budget deficit, e.g., 30.6\% in 1980 and 51.5\% in 1990. As a result, both the rate of growth of M2 and the formal inflation rate stood at high levels during this period (Figure 4).

\section{Figure 4}

Some indicators of economic performance (1975-1990)

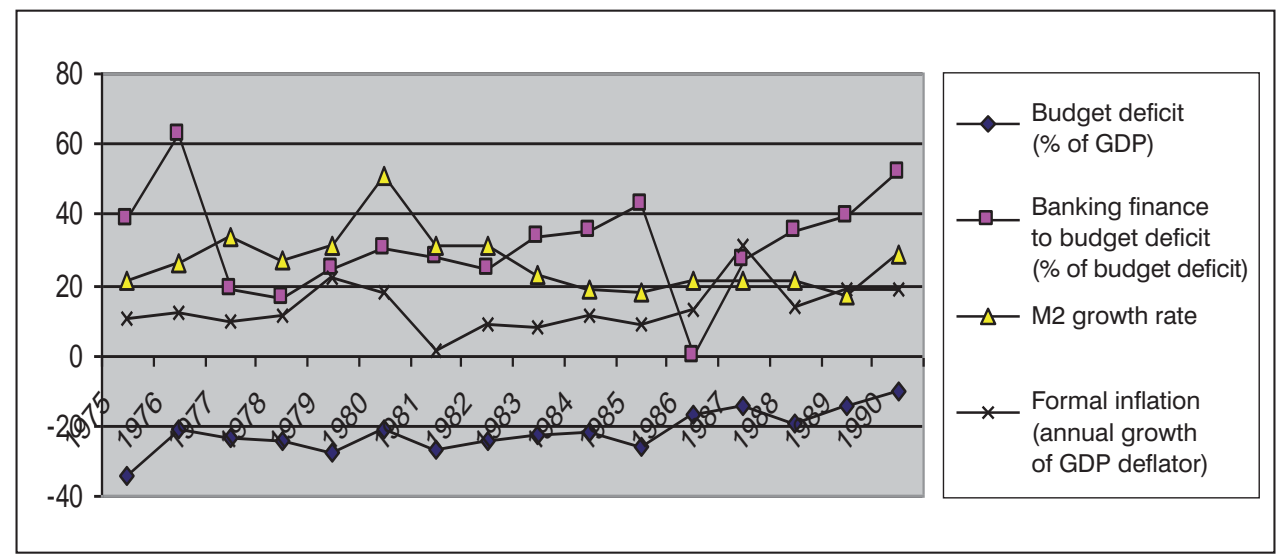

Source: adapted from Awad (2002).

In the late 1980s, the economic performance of the Egyptian economy was critical. A chronic deficit in the general budget supported by banking finance created a demand-pull inflation. The unemployment rate increased continuously and registered high levels at the end of this period. The rate of growth of the GDP was diminishing and approached zero at the end of this period (Figure 5). 


\section{Figure 5}

Some macroeconomic indicators of economic performance (1975-1991)

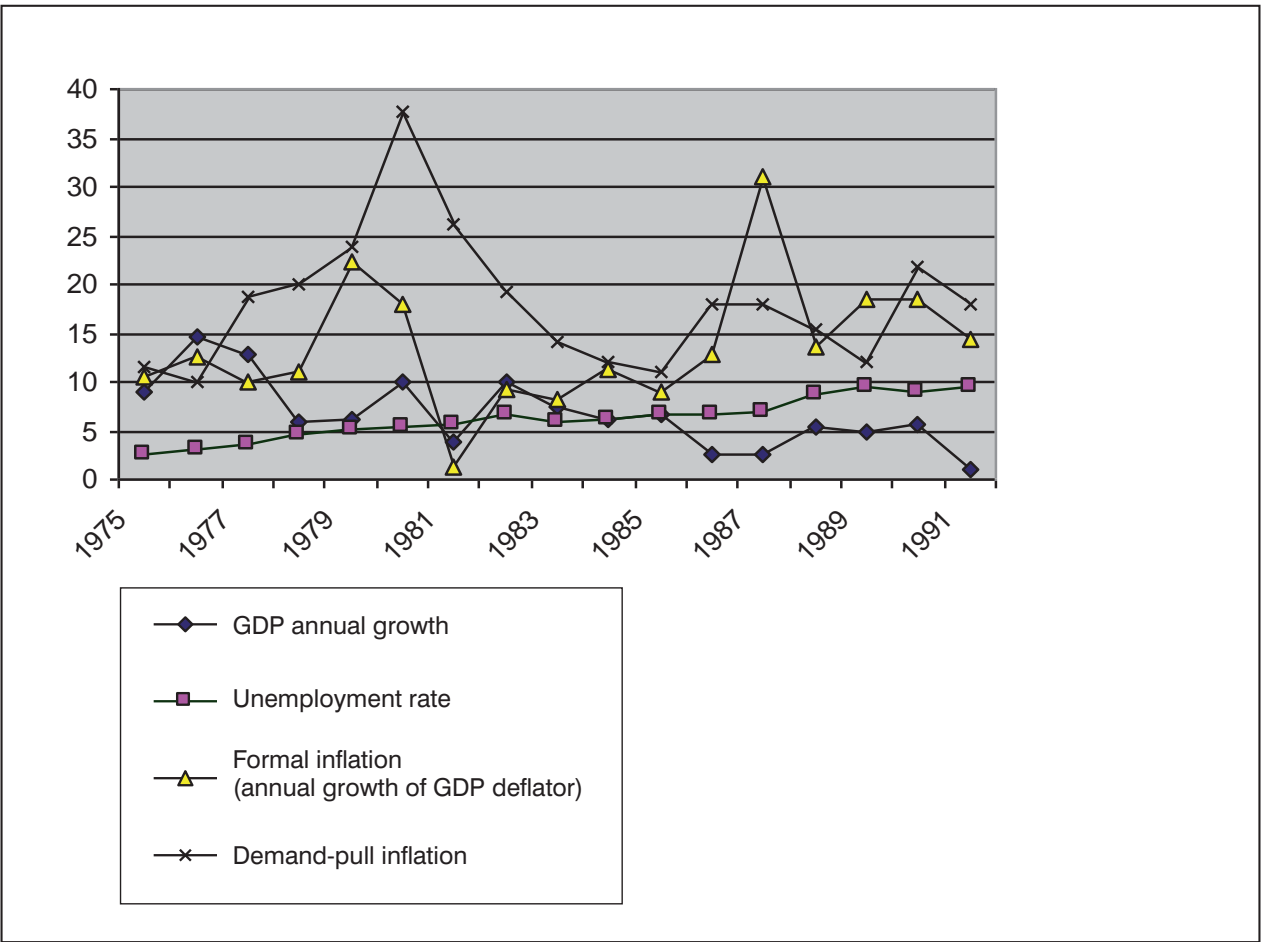

Source: adapted from Awad (2002).

\subsection{The economic performance under the ERSAP}

Table 1 depicts the behavior of the rate of growth of the real GDP, the unemployment rate (\% of the total labor force), and the CPI inflation. Comparing the rate of inflation under the ERSAP, 1991-2008, with the previous period, 1975-1990, Egypt could have brought the rate of inflation down by nearly $50 \%$. Nevertheless, the unemployment rate increased by $66.67 \%$ and the rate of growth of the real GDP slumped by $35.4 \%$. However, the ERSAP did not yet stabilize the economy. The rate of inflation under the ERSAP, nearly $8 \%$ on average, is very high compared to Germany, $2 \%$, during the same periods. ${ }^{13}$

13 One can describe the case depicted in Table 1 as 'stagflation', where higher rates of both inflation and unemployment occur. 
Table 1

Some indicators of macroeconomic performance in Egypt and Germany

\begin{tabular}{|l|c|c|c|}
\hline Average rate (\%) & Real GDP growth & Unemployment & CPI Inflation ${ }^{1}$ \\
\hline Egypt & $7.2^{2}$ & $6^{5}$ & 15.6 \\
\hline $1975-1990$ & 4.65 & 10 & 7.85 \\
\hline $1991-2008^{3}$ & $1.72^{1}$ & $10.71^{4}$ & $2^{1}$ \\
\hline Germany &
\end{tabular}

Sources: ${ }^{1}$ Calculated from IFS, CD-R, 2010. Data for Unified Germany is calculated for the period 1992-2008. ${ }^{2}$ Calculated from WDI, CD-R, 2009. ${ }^{3}$ Calculated from IFS, CD-R, 2010. ${ }^{4}$ Calculated for the period 1993-2008 from IFS, CD-R, 2010. ${ }^{5}$ Calculated from Awad (2002).

The failure to achieve the goal of price stability under the ERSAP can be explained by two reasons, namely, a conflict between monetary policy objectives, i.e., pegging the FX rate and the attempt to use an independent monetary policy to achieve some other goals (e.g., price stability and economic growth), and a chronic deficit in the general budget financed by issuing new money. I will discuss these two reasons in detail.

\subsubsection{Conflict between monetary policy objectives}

As mentioned above, after the introduction of the ERSAP in 1990 and liberalizing the interest rate in 1991, the CBE adopted a dual target policy, i.e., targeting the M2 growth rate and pegging the FX rate vis-à-vis the US dollar.

\section{Figure 6}

\section{The evolution of both CPI inflation and FX rate under the ERSAP}

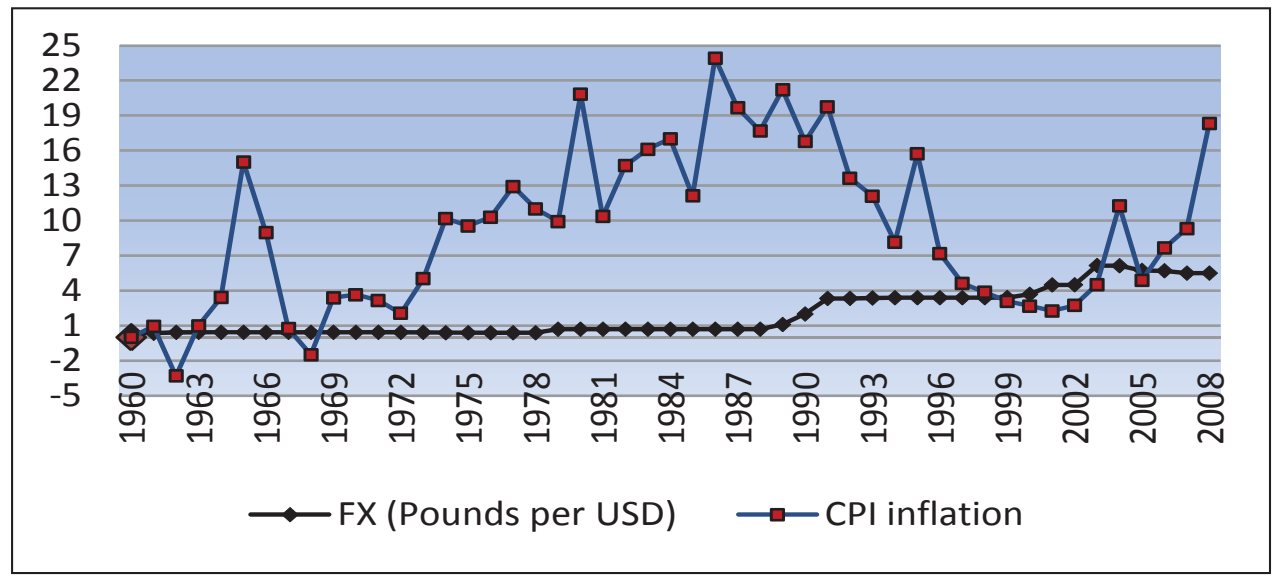

Source: prepared using data from IFS, CD-R 2010 
As Figure 6 indicates, the CBE could have brought the inflation rate down during the 1990s while pegging the FX rate. Nevertheless, the inflation rate was revived once more when the CBE was forced to devaluate the domestic currency as of 2001 in the aftermath of the economic shocks that occurred during the latter half of the 1990s.

Literally, such a policy is both inconsistent and fragile. It is inconsistent because monetary policy cannot simultaneously follow an internal and external policy target under free capital mobility (Flemming, 1962; Mundell, 1963). ${ }^{14}$ Alternatively, a country willing to secure an independent monetary policy along with a fixed exchange rate has two options: to impose control on the international mobility of capital, or to satisfy the net demand for foreign exchange at the fixed FX rate with sterilized foreign exchange intervention. Both the policies are fragile (Goodfriend, 2008).

Under financial liberalization, it becomes very difficult, if not impossible, to impose control on speculative capital flows especially when interest rate differentials are high. Figure 7 and Tables 2 and 3 indicate the following findings: (i) during the period 1995-2003, the CBE intended to maintain the deposit rate, DEPR, higher than the federal fund rate, FFR, as can be inferred from the mean value of the two variables; (ii) according to the standard deviation value , the CBE during this period did not use the deposit rate to support the domestic currency after the economic shocks during the latter half of the 1990s; (iii) according to the correlation coefficient and Granger causality test, the CBE did not follow an independent monetary policy during the above period, where the correlation coefficient between both DEPR and FFR was high, 66\%, and FFR Granger causes DEPR; and (iv) after floating the FX rate in 2003, deposit rates moved gradually to approach FFR as shown in Figure 7.

\section{Figure 7}

Domestic interest rates and federal fund rate (1992-2007)

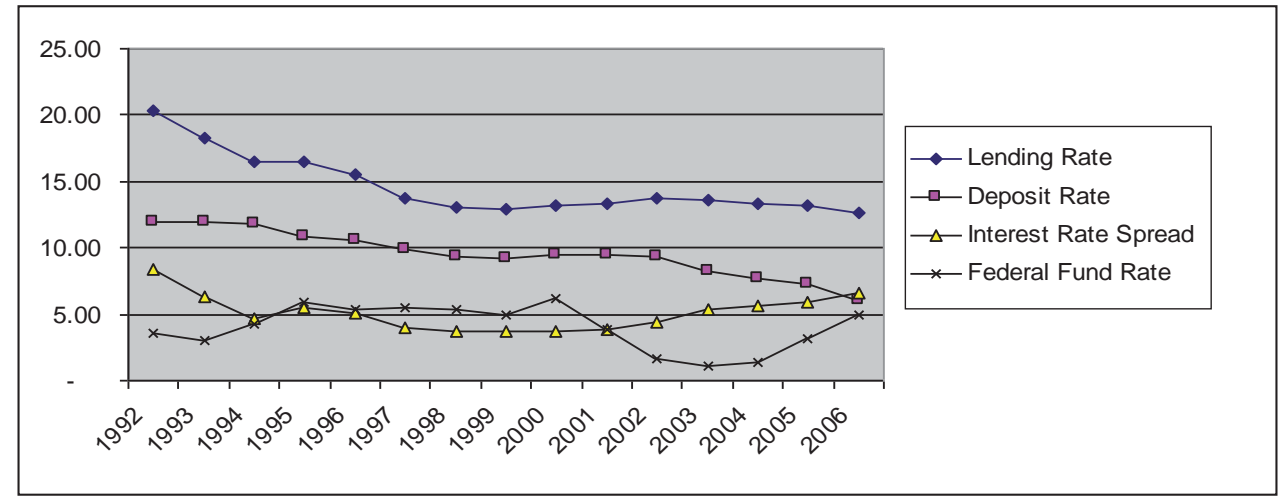

Source: Domestic interest rates for Egypt are adopted from WDI, CD-R 2009; federal fund rates are adoptedfrom IFS, CD-R 2010.

14 This idea is known in literature as the 'impossible trinity hypothesis', i.e., a country can only pick two out of the following three objectives: (i) fixed exchange rate, (ii) free capital mobility, and (iii) monetary policy independence. 
Table 2

Descriptive statistics for deposit rate and federal fund rate

\begin{tabular}{|l|l|l|l|c|}
\hline \multirow{2}{*}{} & \multicolumn{2}{|c|}{$1992-2006$} & \multicolumn{2}{c|}{ 1995-2003 } \\
\cline { 2 - 5 } & DEPR & FFR & DEPR & 4.42 \\
\hline Mean & 9.5 & 4.06 & 9.6 & 1.84 \\
\hline Std. Dev. & 1.75 & 1.7 & 0.78 & 0.66 \\
\hline Correlation & 0.465 & & \\
\hline
\end{tabular}

Source: The author.

Table 3

Pairwise Granger Causality Tests

\begin{tabular}{|l|c|c|c|}
\hline \multicolumn{4}{|l|}{ Sample: $1995-2003$} \\
\hline Lags: $\mathbf{1}$ \\
\hline Null Hypothesis: & Obs. & F-Statistic & Probability \\
\hline FFR does not Granger Cause DEPR & 8 & 9.94539 & 0.02528 \\
\hline DEPR does not Granger Cause FFR & & 0.07590 & 0.79395 \\
\hline
\end{tabular}

The remaining option to secure interest rate policy independence with a fixed FX rate is to satisfy the net demand for foreign exchange at the fixed FX rate with sterilized foreign exchange intervention. Sterilized intervention means that the CB will accommodate capital flows by sterilizing their effect on the money supply. For instance, if the CB were faced by capital outflows that had a negative effect on the money supply, the CB could maintain its target of money supply through purchasing securities (repo) with the same amount of capital outflows. The important issue in such a case, i.e., the case of capital outflows, is the extent to which the CB is ready to defend the pegged rate. When the $\mathrm{CB}$ does not have either enough foreign reserves or the desire to sacrifice a high amount of its foreign reserves, this policy ends with devaluating the domestic currency. The picture becomes darkened when the passthrough effect, which fuels domestic inflation, is high.

The above scenario describes, partly, the monetary policy followed by the CBE from the 1990s until the decision to float the FX rate at the beginning of 2003. It also answers the question why the CBE could not maintain price stability for a long time, especially with successive devaluations of the domestic currency from 2001.

Abu-Elayoun (2003) and Kamar and Bakardzhieva (2003) mentioned a number of external and domestic economic shocks that negatively affected the performance of the external sector especially in the latter half of the 1990s. These economic shocks included: (i) the East Asian crisis in June 1997, which, firstly, provoked capital outflows and negatively affected the performance of capital market investment and, secondly, deteriorated the performance of the trade balance because of devaluation of 
Asian currencies, which made their exports more competitive than Egyptian goods; (ii) the terrorist attack in Luxor in November 1997, which negatively affected the revenues from tourism; (iii) the fall of oil prices in 1998, which exacerbated the negative influence on the current account.

Figure 8

Performance of the external sector under the ERSAP

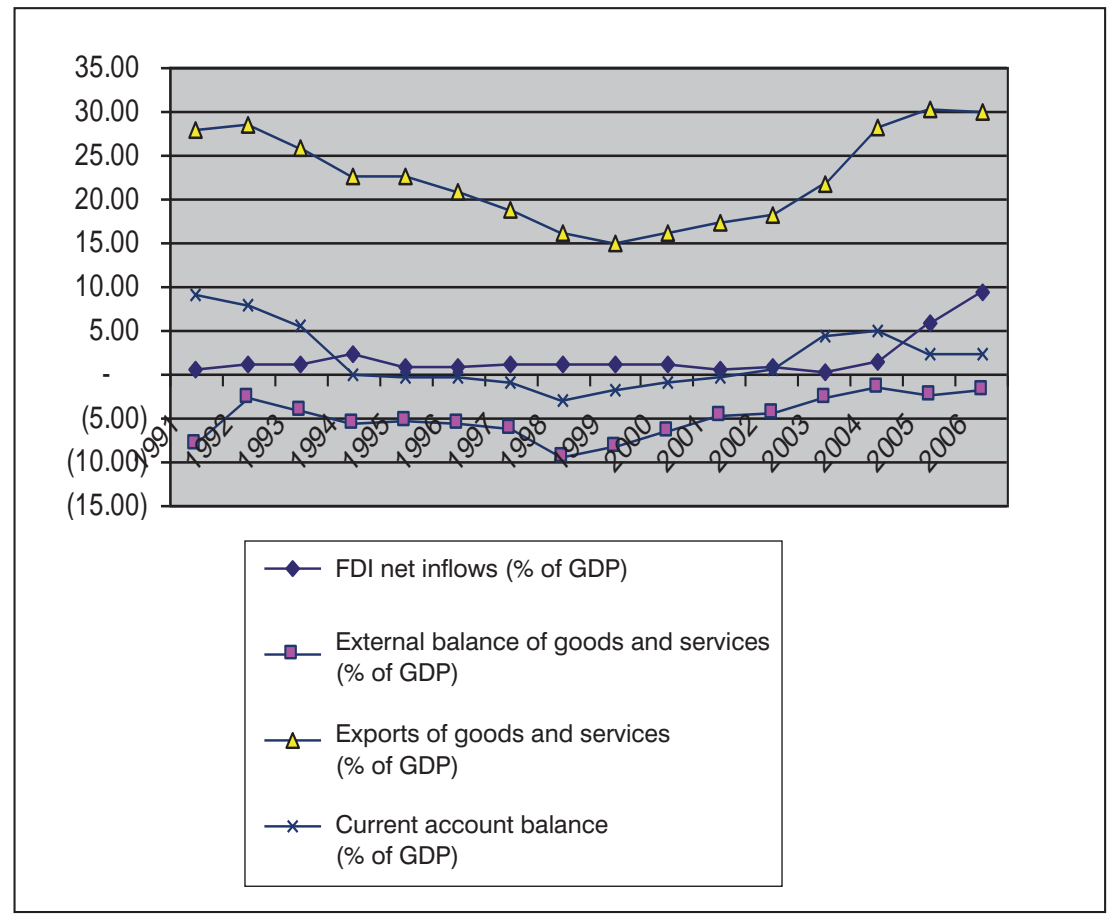

Source: Adapted from Appendix 1, Table 3.

Because of these shocks, the external sector performance and hence the economic performance were negatively affected during the latter half of the 1990s. As shown in Figure 8, the exports (\% of GDP) stepped down (from 22.6\% in 1995 to $16.2 \%$ in 2000), the trade balance deficit went up (from 5.2\% to 6.6\% during the same period), and the current account hit negative values only during this period. However, foreign direct investment (FDI) was nearly at the same level during this period.

Despite the negative consequences of these shocks on the economic performance, the CBE did not respond, i.e., the CBE did not devaluate the domestic currency to support the competitiveness of the export sector by cutting deposit rates. As mentioned above, during this period the CBE was anchoring the domestic currency vis-à-vis the US dollar as a policy target. Another reason that might explain the behavior of the CBE is the concerns of the pass-through effect. Panizza (2001) mentioned that beside 
the economic shocks that negatively affected the current account in the late 1990s, the appreciation of the real exchange rate by itself darkened the picture of the economic performance.

However, as the CBE insisted on defending an unrealistic value of the Egyptian pound during this period, the problems of dollar shortages exacerbated in the economy, ${ }^{15}$ the CBE lost an influential part of its international reserves (during 1998-2000, international reserves decreased from 18 to 14 billion dollars) and the black market FX rate revived in the economy. To stop losses in foreign reserves, the CBE conducted successive devaluations on domestic currency as of 2001 and floated the domestic currency in early 2003. Price levels have gone up since then.

Table 4 sheds light on the variability of the FX rate during the period $1991_{\mathrm{Q} 1}-2008_{\mathrm{Q} 1}$. The low variability of the FX rate during 1991-1999 (0.04) refers to the fixed peg pursued by the CBE during that time. During the period $1999_{\mathrm{Q} 1}-2008_{\mathrm{Q} 1}$, the FX rate variability fell to 0.24 . However, the FX rate variability is still high when compared to the Euro during the same periods.

\section{Table 4}

FX rate variability during the period $1991_{\mathrm{Q} 1}-2008_{\mathrm{Q} 1}$

\begin{tabular}{|c|c|c|c|c|}
\hline Variability & $1991_{Q 1}-1999_{Q 1}$ & $1999_{Q 1}-2003_{Q 1}$ & $2003_{Q 1}-2008_{Q 1}$ & $1999_{\mathrm{Q} 1}-2008_{\mathrm{Q} 1}$ \\
\hline EG/USD & 0.04 & 0.65 & 0.24 & 1.05 \\
\hline EU/USD & $\mathrm{N} / \mathrm{A}$ & 0.09 & 0.07 & 0.15 \\
\hline
\end{tabular}

Source: Calculated from IFS, CD-R 2010

To summarize, a conflict between monetary policy objectives renders the CBE unable to maintain the goal of price stability. Such a conflict is mainly because a monetary policy that includes both internal and external policy targets is fragile by itself. Although the fear of a high pass-through effect represented a justification of pegging the FX rate during the 1990s, the CBE was forced to conduct successive devaluations on the local currency as of 2001 and to float the FX rate in early 2003. After devaluations, domestic prices went up.

\subsubsection{Deficit in the general budget financed by issuing new money}

Although the above conclusion may explain the failure of the CBE to maintain price stability during the periods before floating the FX rate in 2003, it does not completely explain the persistence of high inflation even after the floating of the FX rate. Literally, the floating of the FX rate should have ended a confliction between monetary policy objectives and enable the CBE to pursue the goal of price stability. Floating the foreign exchange rate, firstly, clears the foreign exchange market and, secondly, enables the

15 Although commercial banks declared the price of FX, they did not sell dollars to anyone even in limited amounts. 
interest rate policy to target domestic inflation freely. Nevertheless, the magnitude of the deficit in the general budget and the use of monetary means to finance it can preclude monetary policy from pursuing the goal of price stability.

Table 5 compares budget deficit and CPI inflation (and its variability) in Egypt and Germany. It compares the period 2003-2007, the period after the floating, with the previous periods, 1996-2003, where data for Germany is not available for periods before 1995.

The increase in the budget deficit during the period $2003-2007$ by nearly $73 \%$ compared to previous periods was in conjunction with an increase in the inflation rate by nearly $83 \%$ during the same periods. In addition, the inflation variability worsened during the periods 2003-2007 compared to the previous periods. In general, while low and stable inflation rates were coexisting with a low budget deficit in Germany, high and variable inflation rates were coexisting with a soaring budget deficit in Egypt during the last periods.

\section{Table 5}

Budget deficit and inflation in Egypt and Germany

\begin{tabular}{|c|c|c|c|}
\hline $1996-2003$ & & 2003-2007 & 1995-2007 \\
\hline \multicolumn{4}{|c|}{ Average budget deficit (\% of GDP) } \\
\hline Egypt & 2.8 & 4.84 & 3.17 \\
\hline Germany & 2.14 & 2.07 & 2.1 \\
\hline \multicolumn{4}{|c|}{ Average inflation } \\
\hline Egypt & 3.87 & 7.07 & 6 \\
\hline Germany & 1.34 & 1.6 & 1.5 \\
\hline \multicolumn{4}{|c|}{ Std. Dev. of Inflation } \\
\hline Egypt & 1.6 & 2.71 & 4.05 \\
\hline Germany & 0.47 & 0.39 & 0.44 \\
\hline
\end{tabular}

Source: Calculated from WDI, CD-R 2009.

Literally, fiscal expansion financed by issuing new money can lead to a demand-pull inflation. Figure 9 depicts the behavior of the demand-pull inflation (DPI), the GDP deflator-inflation (GDPD), and the budget deficit (BD). The DPI was calculated using the following formula:

$$
\mathrm{DPI}=[(1+\mathrm{M} 2 \text { growth rate }) /(1+\mathrm{GDP} \text { growth rate })]-1 .^{16}
$$

\footnotetext{
16 This formula is derived from the quantity equation:

$\mathrm{M} \mathrm{x} \mathrm{v}=\mathrm{p} \mathrm{x} \mathrm{q} \mathrm{(1).} \mathrm{At} \mathrm{the} \mathrm{end} \mathrm{of} \mathrm{the} \mathrm{year,} \mathrm{Equation} \mathrm{(1)} \mathrm{can} \mathrm{be} \mathrm{written} \mathrm{as} \mathrm{follow:}$

$M(1+R m) \times v(1+R v)=p(1+R p) \times q(1+R q)(2)$, where $R m, R v, R p$ and Rq are the M2 growth rate, $v$, $p$ and $q$.

Let $\mathrm{Rv}=0$, under the assumption that (v) is constant, and divide (2) by (1); this yields the formula used in the text; $\mathrm{Rp}=(1+\mathrm{Rm}) /(1+\mathrm{Rq})-1$ (3). It is important to notice that even if we dropped the above assumption, the value of the demand-pull inflation would not change so much or it not on average.
} 


\section{Figure 9}

Demand-pull inflation, formal inflation and budget deficit (1974-2007)

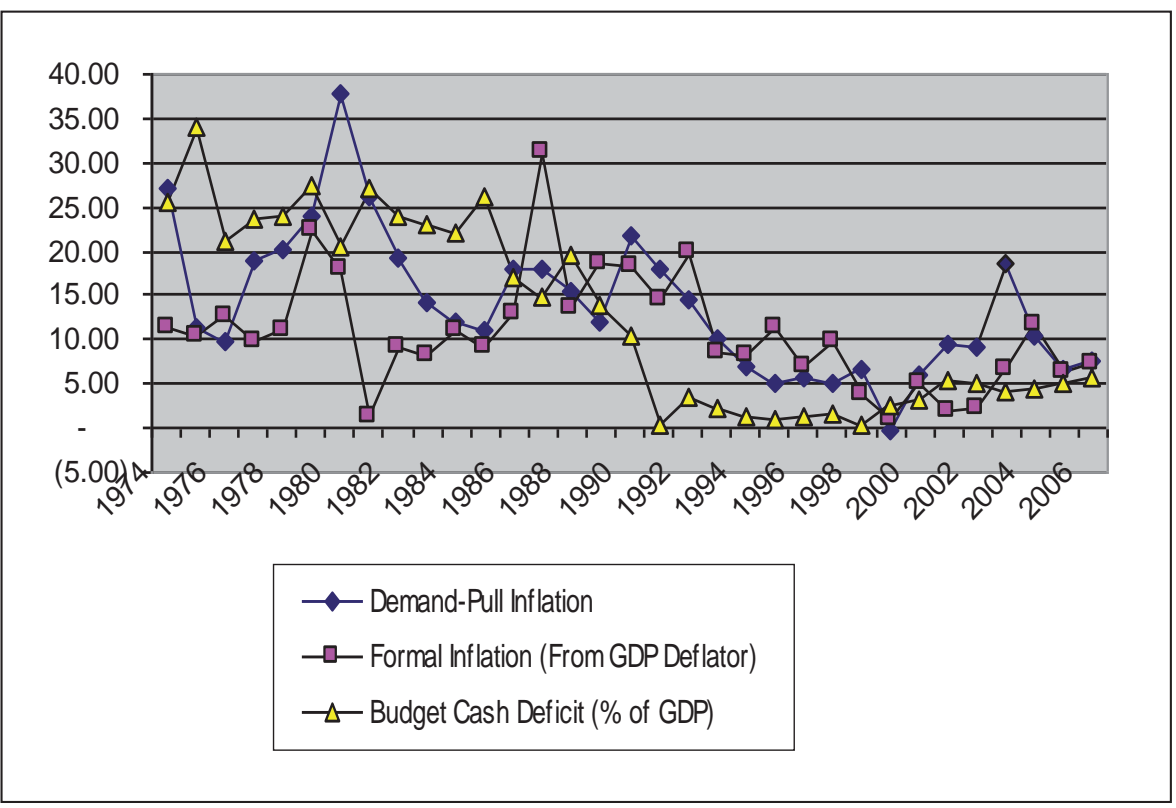

Source: prepared using data from Awad (2002) and WDI, CD-R 2009.

The difference between DPI and open inflation (measured by annual change in GDPD) represents the suppressed inflation, that is,

Suppressed Inflation = Demand-pull inflation - Open Inflation .

As mentioned, before the 1990s, the suppressed inflation was high because the government was controlling price levels. After the introduction of the ERSAP, the suppressed inflation receded as the government privatized the economy and liberalized most prices. ${ }^{17}$ This point is obvious if we compare the correlation coefficients between GDPD and DPI for the periods 1991-2007 (Table 8), being 51\%, with the correlation coefficients for the periods 1974-2007 (Table 6), being 44.6\%.

However, the important issue here is that a high correlation is found between DPI and $\mathrm{BD}, 58.5 \%$, as shown in Table 6. Moreover, according to the Granger causality test for the period 1974-2007 (Table 7) BD Granger causes DPI. During the period 1991-2007, the correlation between GDPD and DPI was high, as mentioned, and BD (Granger) causes DPI at a 10\% level (Table 9).

17 The contribution of the private sector to the real GDP has increased after the introduction of the ERSAP to more than $67 \%$ on average compared to $25 \%$ in the past (calculated from the data available on the CBE website: http://www.cbe.org.eg/timeSeries.htm). 
Table 6

Correlation coefficient matrix during the period 1974-2007

\begin{tabular}{|l|c|c|c|}
\hline & GDPD & DPI & BD \\
\hline GDPD & 1 & 44.6 & 23.5 \\
\hline DPI & & 1 & 58.5 \\
\hline BD & & & 1 \\
\hline
\end{tabular}

\section{Table 7}

Granger causality tests 1974-2007

\begin{tabular}{|l|c|c|c|}
\hline \multicolumn{4}{|l|}{ Sample: $1974-2007$} \\
\hline Lags: 2 \\
\hline Null Hypothesis: & Obs. & F-Statistic & Probability \\
\hline BD does not Granger Cause DPI & 31 & 5.17808 & 0.01280 \\
\hline DPI does not Granger Cause BD & & 0.31688 & 0.73119 \\
\hline
\end{tabular}

Table 8

Correlation coefficient matrix during the period 1991-2007

\begin{tabular}{|l|c|c|c|}
\hline & GDPD & DPI & BD \\
\hline GDPD & 1 & 51 & -26.3 \\
\hline DPI & & 1 & 11.3 \\
\hline BD & & & 1 \\
\hline
\end{tabular}

Table 9

Granger causality tests 1991-2007

\begin{tabular}{|l|c|c|c|}
\hline Sample: $1991-2007$ \\
\hline Lags: 2 \\
\hline Null Hypothesis: & Obs. & F-Statistic & Probability \\
\hline BD does not Granger Cause DPI & 14 & 4.01572 & 0.05668 \\
\hline DPI does not Granger Cause FFR & & 1.38529 & 0.29888 \\
\hline
\end{tabular}

Figure 10 sheds light on the contribution of the banking system (including the CBE) to financing the budget deficit (cash) during the period 1975-2005. During the first half of the 1990s, the government used treasury bills to finance the budget 
deficit. Therefore, banking finance to the budget deficit was negative during this period (1990/1991-1994/1995) at 31.2\%. In the latter half of the 1990s (1995/19961999/2000), banking finance to the budget deficit was nearly $96.75 \%$. Thus, for the whole period (1990/1991-1999/2000), it reached 33\% on average.

\section{Figure 10}

Budget deficit and banking finance to budget deficit (1975-2006)

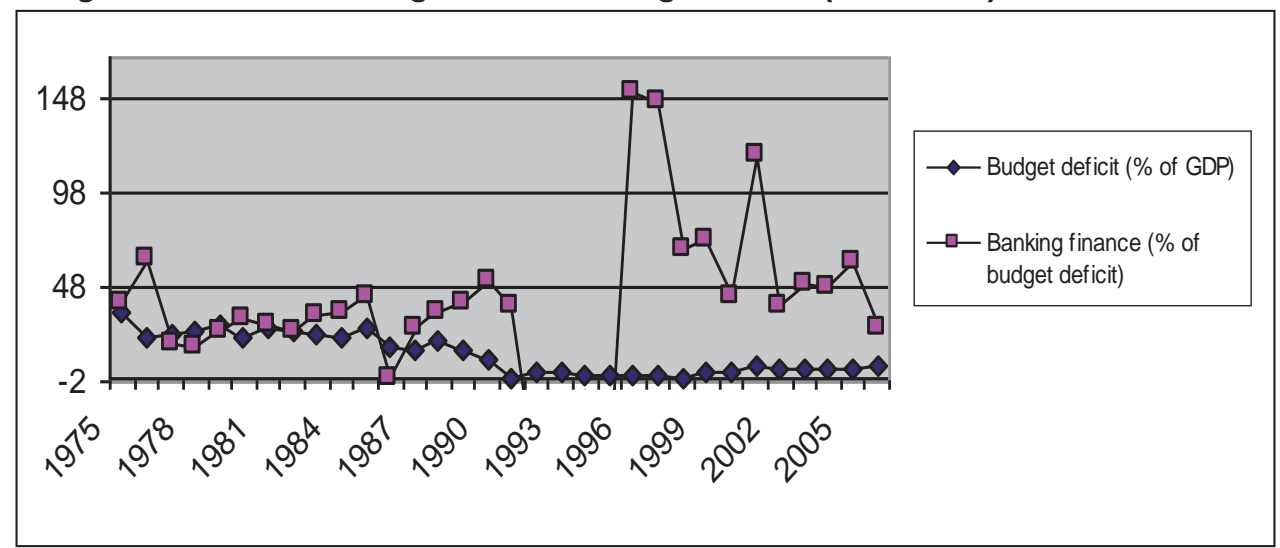

Source: Prepared using data from Appendix 1, Table 1.

Table 10

Budget deficit and sources of financing during the period 2001/02-2006/07

\begin{tabular}{|l|c|c|c|c|c|c|}
\hline Description & $\mathbf{2 0 0 1 / 2 0 0 2}$ & $\mathbf{2 0 0 2 / 2 0 0 3}$ & $\mathbf{2 0 0 3 / 2 0 0 4}$ & $\mathbf{2 0 0 4 / 2 0 0 5}$ & $\mathbf{2 0 0 5 / 2 0 0 6}$ & $\mathbf{2 0 0 6 / 2 0 0 7}$ \\
\hline Cash deficit (\% GDP) & 9.8 & 9.1 & 9.1 & 9.4 & 9.2 & 5.7 \\
\hline Overall deficit (\% GDP) & 10.2 & 10.4 & 9.5 & 9.6 & 8.2 & 7.5 \\
\hline $\begin{array}{l}\text { Domestic financing } \\
\text { (\% overall deficit) }\end{array}$ & 80 & 82.5 & 98.8 & 123 & 108 & 61 \\
\hline $\begin{array}{l}\text { Banking financing } \\
\text { (\% domestic financing) }\end{array}$ & 47 & 54 & 46.3 & 49.4 & 27 & - \\
\hline $\begin{array}{l}\text { CBE financing } \\
\text { (\% banking financing) }\end{array}$ & 41 & 27 & 112 & 79 & $(77.5)$ & 15 \\
\hline
\end{tabular}

${ }^{1}$ Pre-actual data, ${ }^{2}$ Cash deficit $=$ Total revenues - Total expenditures, ${ }^{3}$ Overall deficit $=$ Cash deficit + Net acquisition of financial assets.

Source: Calculated from http://www.cbe.org.eg/timeSeries.htm.

In addition, the CBE is regularly financing the budget deficit via issuing new money ('seigniorage'). ${ }^{18}$ Table 10 shows budget deficits and domestic sources of

18 The role of the CBE in financing the budget deficit was not interrupted during the periods before the introduction of the ERSAP and even after the ERSAP. The new legislation on the CBE, the banking sector, and the money issued in 2003 obliged the CBE to finance the budget deficit. 
financing during the period 2001/02-2006/07. The high numbers of both cash deficit and overall deficit are supported by high contributions of the CBE to financing the budget deficit. The contribution of the CBE to financing the budget deficit will cause an increase in the money supply; thereby, the price level will soar. That explains the causality between the budget deficit and the demand-pull inflation in Egypt as shown in Table 9. In other words, the causality between the budget deficit and the demand-pull inflation in Egypt is because the CBE is obliged to finance the budget deficit.

To summarize, the failure of the CBE to maintain price stability even after floating the FX rate in 2003 is explained by the high budget financed by means of issuing new money. The increase in the budget deficit especially after 2003 and the use of monetary means to finance it have created a demand-pull inflation. Since the majority of prices became free after the introduction of the ERSAP, the demand-pull inflation expressed itself through a growing formal price level measured by the GDP deflator.

\section{Conclusions}

This paper assesses the performance of the monetary policy in Egypt during the periods following the introduction of the ERSAP in the early 1990s. The paper intends to answer the question why the CBE has not been able not achieve the goal of price stability under the ERSAP. The study compares economic performance since the 1990s with both its counterpart in Germany, during the same periods, and with the economic performance of the Egyptian economy during the periods before the 1990s, i.e., $1975-1990$.

The main conclusion of the study is that although Egypt could have brought the inflation rate down after the introduction of the ERSAP, the unemployment and real GDP growth rates have worsened, and price stability was not attained. The failure to achieve the goal of price stability is explained by two reasons: (i) a conflict between monetary policy objectives which renders the CBE unable to efficiently use monetary policy tools to maintain the goal of price stability; (ii) a high budget deficit financed by the issuing of new money, which fuels a demand-pull inflation.

In the light of this, to improve the performance of the monetary policy in Egypt in the future, the CBE should be factually independent. In addition, the CBE should not maintain an implicit target for other variables, e.g., the FX rate. As indicated by Awad (2008), the CBE is not factually independent. A CB is factually independent if it satisfies three conditions (Awad, 2009): (i) legal instrument independence; (ii) nonexistence of government representatives in the Monetary Policy Committee as voting members; and (iii) no obligation for the $\mathrm{CB}$ to finance budget deficit. 


\section{References}

ABU-ELAYOUN, M. 2003. Monetary Policy in Egypt: A version for future (Arabic). [Working Paper, No 78]. [Online]. ECES, 2003. www.eces.org.eg/Publications/View_Pub.asp?p_id=10\&p_ detail_id=134\#mytop.

AL-MASHAT, R. 2008. Monetary Policy in Egypt: A Retrospective and Preparedness of Inflation Targeting [Working Paper No. 134]. [Online]. ECES, 2008. www.eces.org.eg/Publications/View_Pub. asp?p_id=10\&p_detail_id=18\#mytop.

AWAD, I. L. 2002. The Phenomenon of Stagflation in the Egyptian Economy: Analytical study (Arabic). [Online]. Zagazig University, Faculty of commerce, 2002. http://econpapers.repec.org/ scripts/redir.pl?u=http\%3A\%2F\%2Fmpra.ub.uni-muenchen.de\%2F5465\%2F01\%2FMPRA_ paper_5465.pdf; $h=$ repec:pra:mprapa:5465.

AWAD, I. L. 2008. Towards Measurement of Political Pressure on Central Banks: The case of the Central Bank of Egypt. Prague Economic Papers. 2008, vol. XVII, no 3, s. 254-275.

AWAD, I. L. 2009. Did Egypt Satisfy Prerequisites for an IT Regime? Acta Oeconomica Pragensia. 2009, vol. 17, no 6, s. 63-80.

BATINI, N.; KUTTNER, K.; LAXTON, D. 2005. World Economic Outlook: Building Institutions, Ch. IV. [Online]. IMF, September, 2005. www.imf.org/external/pubs/tt/weo/2005/02/index.htm.

CBE (2002-2003). Economic Review [Online]. Vol. 43, no. 4. www.cbe.org.eg/Publications.htm.

CBE (2005-2006). Economic Review [Online]. Vol. 46, no. 1. www.cbe.org.eg/Publications.htm.

CBE (2006-2007). Economic Review [Online]. Vol. 47, no. 2. www.cbe.org.eg/Publications.htm.

FLEMMING, M. J. 1962. Domestic Financial Policies under Fixed and under Floating Exchange Rates. IMF Staff Papers. 1962, vol. 9, s. 369-379.

GALAL, A. 2003. To Float or Not Float: That is No Longer the Question for Egypt [Policy Viewpoint No. 13]. ECES, 2003.

GOODFRIEND, M. 2008. The Case for Price Stability with a Flexible Exchange Rate in the New Neoclassical Synthesis. Cato Journal. 2008, vol.25, no. 2, s. 247-254.

KAMAR, B.; BAKARDZHIEVA, D. 2005. Economic Trilemma and Exchange Rate Management in Egypt. Review of Middle East Economics and Finance. 2005, vol. 3, no. 2. [Online]. www.bepress.com/rmeef/vol3/iss2/art1.

KORAYEM, K. 1997. Egypt's Economic Reform and Structural Adjustment [Working Paper No.19]. ECES, 1997.

MOURSI, T. A.; MAI, E. M.; ZAKAREYA, E. 2007. Effects of Some Recent Changes in Egyptian Monetary Policy: Measurement and Evaluation [Working Paper No. 122]. ECES, 2007.

MUNDELL, R. 1963. Capital Mobility and Stabilization Policy under Fixed and Flexible Exchange Rates. Canadian Journal of Economics and Political Science. 1963, vol.29, s. 475-485.

NASSAR, H. A. 1989. Unemployment and Investment Policies. In SOLIMAN, S. (ed.). Unemployment in Egypt. Cairo : Faculty of Economics and Social Sciences, 1989.

PANIZZA, U. 2001. Macroeconomic policies in Egypt: An Interpretation of the Past and Options for the Future [Working Paper No. 61]. [Online]. ECES, 2001. www.eces.org.eg/Uploaded_ Files/\%7BEA853B45-7859-4B86-8281-9877B386B4CC\%7D_ECESWP61e.pdf.

RICHARDS, A. 2001. The Political Economy of Economic Reform in the Middle East: The Challenge to Governance. Santa Cruz : University of California, 2001. 


\title{
WHY HAS THE CENTRAL BANK OF EGYPT BEEN UNABLE TO ACHIEVE THE GOAL OF PRICE STABILITY UNDER THE ECONOMIC REFORM PROGRAM?
}

\begin{abstract}
This paper assesses the performance of the monetary policy in Egypt during the periods following the introduction of the economic reform and structural adjustment program (ERSAP). It sets out to answer the question why the Central Bank of Egypt (CBE) has not been able to achieve the goal of price stability under the ERSAP? The study compares the economic performance from the 1990s with both its counterpart in Germany, during the same periods, and with the economic performance of the Egyptian economy during the periods before the 1990s, i.e., 1975-1990. The study concludes that the CBE could have brought the rate of inflation down; nevertheless, the unemployment and real GDP growth rates have worsened and a price stability is still far away. The failure to achieve price stability is explained by two reasons, namely, a conflict between monetary policy objectives and a chronic budget deficit financed by issuing new money.
\end{abstract}

Keywords: Price Stability; Monetary Policy Objectives; Economic Reform in Egypt

JEL Classification: E31,E40, E42, E50 